\title{
Strengths and Weaknesses of the Dutch Implementation of the Water Framework Directive
}

\author{
Lorenzo Squintani \\ University of Groningen, the Netherlands \\ l.squintani@rug.nl \\ Ernst Plambeck \\ Utrecht Centre for Water, Oceans and Sustainability Law, Utrecht University, \\ the Netherlands \\ e.j.h.plambeck@uu.nl \\ Marleen van Rijswick \\ Utrecht Centre for Water, Oceans and Sustainability Law, Utrecht University, \\ the Netherlands \\ h.vanrijswick@uu.nl
}

\begin{abstract}
The Netherlands has a long and fascinating history of water management. The main features of the Dutch water governance system for the implementation of the WFD are its regional water authorities based on hydrological scales and powers to regulate, decide and raise taxes for their water tasks. Their functional approach and the decentralised character make the regional water authorities very efficient and effective. It is therefore understandable that EU institutions and other Member States consider the Dutch system an interesting potential source of inspiration for other jurisdictions. Yet, it is not all gold what shines. This paper highlights the strength and weakness elements of the Dutch water governance system under the WFD. It exposes several points of concern. When considering using the Dutch experience as a source of inspiration in other Member States, these concerns should be taken in due account.
\end{abstract}




\section{Keywords}

Water Framework Directive - programmatic approach - no derogation - monitoring - quality standards

\section{Introduction}

The Netherlands has a long and fascinating history of water management. In 2014 the OECD stated that Dutch water governance can serve as an example for the world. ${ }^{1}$ However, an aspect that should be improved according to the OECD is the protection and improvement of water quality, as follows from the requirements of the Water Framework Directive (WFD ). ${ }^{2}$ As a result of the OECD's recommendations the Dutch government started a new approach to improve the status of Dutch waters, called the 'Delta-approach water quality' (Delta-aanpak waterkwaliteit) ${ }^{3}$ referring to the famous Dutch Delta works and the Delta programme that has been developed for water management in times of climate change. The Delta-approach water quality is not based on new legislation but it is an declaration of intent between all stakeholders involved to come to a new water governance agreement with explicit attention to improving water quality.

The long history of Dutch water management and governance offered many lessons to improve water governance in the country throughout the centuries. ${ }^{4}$ Due to its geographical position and its vulnerability to flooding the focus has traditionally been on water quantity, drainage and flood protection. The implementation of the first generations of EU water directives has been rather successful, with the Nitrates directive as an exemption. ${ }^{5}$ The Netherlands was strongly involved with the development of the WFD and the approach taken in

1 OECD (2014), Water Governance in the Netherlands: Fit for the Future?, oECD Studies on Water, OECD. Publishing. http://dx.doi.org/10.1787/9789264102637-en (Accessed October 2017).

2 Directive 2000/6o/EC of the European Parliament and of the Council of 23 October 2000 establishing a framework for Community action in the field of water policy, [2000] OJ L 327/1.

3 See https://www.rijksoverheid.nl/documenten/rapporten/2016/11/o7/intentieverklaring-del ta-aanpak-waterkwaliteit-en-zoetwater-tussen-overheden-maatschappelijke-organisaties -en-kennisinstituten (last visited October 2017).

4 H.F.M.W. van Rijswick \& I.M. Tappeiner, Developing an institutional legal framework for sustainable regional water management in times of climate change, in M. Kidd et al. (eds.), Water and the Law, Towards Sustainability, Edward Elgar Publishing, 2014 , pp. 274-304.

5 Case C-322/oo, Commission v The Netherlands, ECLI:EU:C:2003:532. 
the Directive seemed to match rather perfect with the Dutch approach. ${ }^{6}$ However, the more the implementation process proceeded, the more uncertainties raised about the exact meaning of the obligations following from the Directive, ${ }^{7}$ resulting in a rather limited level of ambition, at least written down in the first river basin management plans. ${ }^{8}$ In recent years a need for comparative research regarding the implementation of the WFD was felt, resulting in journal papers, ${ }^{9}$ and active involvement in international conferences and networks such as the European Network for Water Law/Reseau d'eau. The existence of regional water authorities made it easy to implement the river basin approach, and also the cost recovery for water services was already an existing element in Dutch water management. ${ }^{10}$ Moreover, the fact that most of the older water directives had already been implemented rather well made it possible to focus on the WFD itself. There is thus something to learn from the Dutch experience.

Yet, water quality in the Netherlands is not good, ${ }^{11}$ and a recent prediction made by the Netherlands Environmental Assessment Agency (Planbureau voor de Leefomgeving), ${ }^{12}$ shows that by 2027 between $95 \%$ and $60 \%$ of Dutch waters will not fulfil the standards established under the Water Framework

$6 \quad$ H.F.M.W. van Rijswick, Interaction between European and Dutch Water Law, in S. Reinhard $\&$ H. Folmer (eds.), Water Policy in the Netherlands, Integrated Management in a Densely Populated Delta, Issues in water resource policy, Washington: RF F Press, 2009, pp. 204-224.

7 G.T. Raadgever et al., Uncertainty management strategies: Lessons from the regional implementation of the Water Framework Directive in the Netherlands, Environmental Science and Policy, 2011, 14 (1), pp. 64-75.

8 C. Dieperink et al., Ecological ambitions and complications in the regional implementation of the water framework directive in the Netherlands. Water Policy, 2012, 14 (1), pp. 160-173; H.F.M.W. van Rijswick \& A.M. Keessen. The implementation of the first generation river basin management plans in Dutch water law, lessons from the past, lessons for the future, Romanian journal of Environmental law, 2012, pp. 262-273.

9 A.M. Keessen et al., European River Basin Districts: Are They Swimming in the Same Implementation Pool?, JEL 2010 (2), pp. 197-222.

10 P. Lindhout, Cost recovery as a policy instrument to achieve sustainable and equitable water use in Europe and the Netherlands, diss. Utrecht University 2015, Uitgeverij 2VM.

11 СвS, PBL, Wageningen UR, Waterkwaliteit KRW, 2015 (indicator 1438, versie 07, 12 januari 2016). www.compendiumvoordeleefomgeving.nl; http://www.compendiumvoordeleefomgeving.nl/indicatoren/nl1438-Kwaliteit-oppervlaktewater-KRW.html?i=2-76 (Accessed April 2016). See more extensively F.W. van Gaalen e.a., Waterkwaliteit nu en in de toekomst. Eindrapportage ex ante evaluatie van de Nederlandse plannen voor de Kaderrichtlijn Water, Den Haag: PBL 2016.

12 W. Ligtvoet et al., Waterkwaliteit en -veiligheid. Balans van de Leefomgeving 2014 - Deel 6, Den Haag: Planbureau voor de Leefomgeving 2014. See also http://themasites.pbl.nl/ balansvandeleefomgeving/2014/waterkwaliteit (accessed April 2016). 


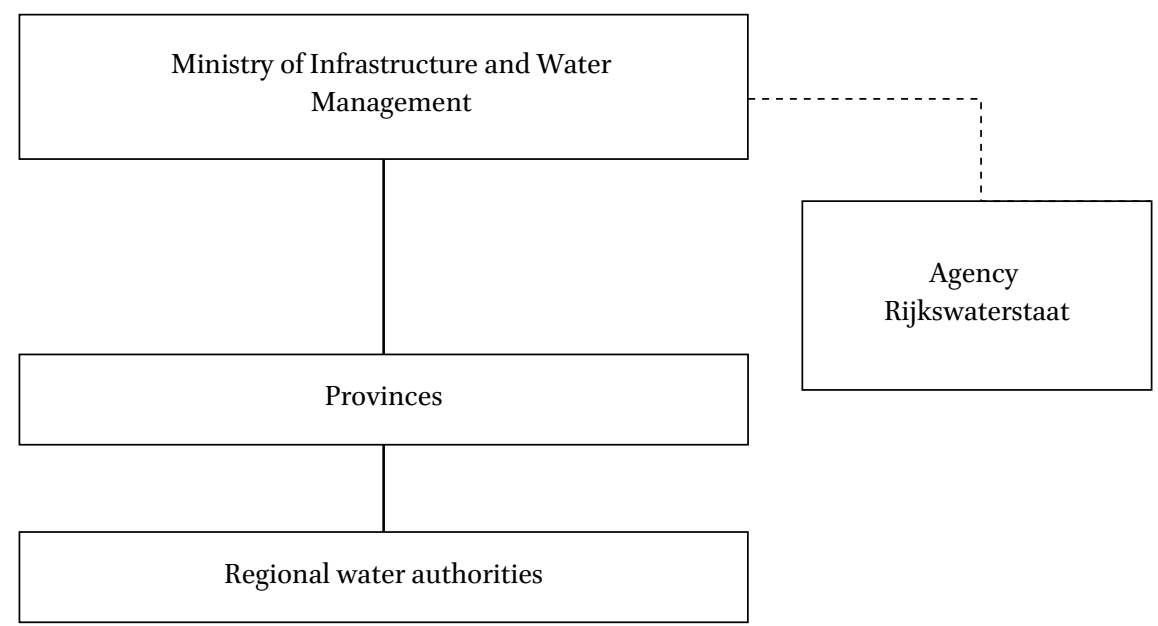

FIGURE 1 Administrative structure of the Netherlands with regard to water quality

Directive (WFD). ${ }^{13}$ Clearly, despite the long withstanding Dutch experience in water management, the effectiveness of implementation of the WFD and the Nitrates Directive can be improved. ${ }^{14}$ This paper highlights the strength and weakness elements of the Dutch water governance system under the WFD. ${ }^{15}$

In section 2 we provide a short description of the Dutch water management system with regard to water quality, which shows the strengths of the system. In section 3, we focus on the points of concern as regards the implementation of the WFD. It shows that in the Netherlands the linkage between the quality objectives under Article 4 of the Directive and the authorisation of specific projects is only an indirect one, i.e. through the medium of the programme of measures adopted for a specific water body. Moreover, we show that the binding character of the quality objectives under Article 4 of the Directive is not as

13 Directive 2000/6o/EC of 23 October 2000 establishing a framework for Community action in the field of water policy [2000] oJ L $327 / 1$.

14 A.M. Keessen et al., The Need for Flexibility and Differentiation in the Protection of Vulnerable Areas in EU Environmental Law: The Implementation of the Nitrates Directive in the Netherlands, JEE PL, 2011 (2), pp. 141-164.

15 This paper builds on, updating them, E. Plambeck, L. Squintani \& M. van Rijswick, Towards more effective protection of water resources in Europe by improving the implementation of the Water Framework Directive and the Aarhus Convention in Netherlands, in S. Maljean-Dubois (ed.), chapter 11; and E. Plambeck \& L. Squintani, De bescherming en verbetering van de waterkwaliteit in Nederland, of: een troebele implementatie van de KRW, M en R, 2017(1), 2-14. 
clearly formulated as the Directive requires. As a consequence, in the Netherlands there is too much room for applying a so-called net-loss approach. ${ }^{16}$

In light of the findings shown in section 3 , we formulate a series of considerations that should be addressed when considering the Netherlands an example to follow in other legal traditions.

\section{$2 \quad$ The Dutch Water Management System}

In the Netherlands, as a decentralised unitary state, there are four kind of administrative bodies responsible for water quality policy. The Ministry of Infrastructure and Water Management and provinces as generic administrative bodies, the regional water authorities as functional decentralized bodies, ${ }^{17}$ and Rijkswaterstaat (RWs) as executive agency responsible for implementing the policies and regulations of the Ministry of Infrastructure and Water Management, with six national and seven regional divisions. ${ }^{18}$ There is a top-down hierarchical relationship between the state, the provinces, and the regional water authorities (see figure 1). Municipalities have a relative small task in water quality management, they are responsible for waste water collection (but not the treatment) and for granting licenses for discharges of polluted waste water in the sewerage system. Nowadays almost all these discharges have been regulated by means of general rules that replace the requirement of a license.

There are twelve provinces, governed by a directly elected Provincial Council (Provinciale Staten) and the Provincial Executive (Gedeputeerde Staten). All regional water authorities, ${ }^{19}$ in total 22, have a general council (Algemeen Bestuur) consisting of directly elected members and appointed representatives of several stakeholder groups, and an executive administration (Dagelijks Bestuur). ${ }^{20}$

Typical features of Dutch water law are continuity, functional approach and decentralised character. ${ }^{21}$ Since the $13^{\text {th }}$ century regional water authorities exist to keep people safe from floods and over the years their powers extended to cover water management, water quantity and water quality. The authorities

16 Dutch academics speak of a 'per balance' approach, e.g. M. Boeve \& B. van den Broek, 'The Programmatic Approach; a Flexible and Complex Tool to Achieve Environmental Quality Standards', (2012) 8 Utrecht Law Review, pp. 74-85, at 78.

17 See more extensively on the functional and decentral character of the regional water authorities, H.F.M.W. van Rijswick \& H.J.M. Havekes, European and Dutch Water Law, Europa Law Publishing, pp. 93-94 and $146 \mathrm{ff}$.

18 See for more information https://www.rijkswaterstaat.nl/english.

19 See for more information www.dutchwaterauthorities.com.

20 Extensively, Van Rijswick \& Havekes supra note 17, pp. $170 \mathrm{ff}$.

21 Id. pp. $92 \mathrm{ff}$. 
are organised bottom-up and water law is born in practice. ${ }^{22}$ The next feature is strongly linked with continuity. Water legislation in the Netherlands is objectoriented, namely water systems. In the beginning, each individual polder and territory has its own authority. Over the time, these authorities merge into the current number but still their powers are defined in accordance with natural, geographical and hydrological formations: river basins. Last, but not least the regulating and deciding powers rests mainly by the regional water authorities, except for national waters which are governed by the State. ${ }^{23}$ The legal basis for their existence is laid down in Article 133 of the Constitution. ${ }^{24}$ Some powers and especially control mechanisms rests by other institutions as provinces and the State. However, in Acts of Parliament is laid down how these can be executed. ${ }^{25}$ Furthermore, the implications for water has to be taken into account by those other institutions using some of their powers. ${ }^{26}$ This leads to integrated water management by way of cooperation and coordination. Another very important notion is that they are endowed with the power to raise taxes for their executive tasks and therefore have their own elections. ${ }^{27}$ So, the no taxation without representation principle is applied. The main advantage of levying their own taxes is that regional water authorities have a stable income to spend for their tasks. ${ }^{28}$ Additionally and even more important it does not have to battle with other politically objectives as wealth care and education. ${ }^{29}$ In fact, the functional approach and the decentralised character make the regional water authorities very efficient and effective.

With regard to water quality, the main instruments are laid down in the Water Act (Waterwet). ${ }^{30}$ There are the plans and programmes, laid down in chapter 4 of the Water Act, and further elaborated in chapter 4 of the Water Decree (Waterbesluit). These chapters refer to four kinds of plans: the national water policy plan of the central government, regional water policy plans of the provinces, the management plans of the Ministry of Infrastructure and Water Management for state waters, and the management plans of the regional water authorities for regional waters. ${ }^{31}$ These plans and programmes must consist

$\begin{array}{ll}22 & \text { Ib-idem. } \\ 23 & \text { Id. pp. } 94 \mathrm{ff} . \\ 24 & \text { On the actual status and shifts over the centuries, see } i d, \text { pp. } 136 \mathrm{ff} . \\ 25 & \text { Id. pp. } 197 \mathrm{ff} . \\ 26 & \text { Id. pp. } 201 \mathrm{ff} . \\ 27 & \text { Id. pp. } 161 \mathrm{ff} . \\ 28 & \text { Id. pp. } 188 \mathrm{ff} . \\ 29 & \text { Ib-idem. } \\ 30 & \text { Id., pp. } 108 \mathrm{ff} . \\ 31 & \text { Id., pp. } 215 \mathrm{ff} .\end{array}$


of among others the 'river basin management plans' (Art. 13 of the WFD) and 'programmes of measures' (Art. 11 of the WFD). Furthermore, discharges into surface waters are, according to Article 6.2 of the Water Act, prohibited without consent by a permit, or by general applicable rules. The general applicable rules are laid down in Orders of Council emanated from the central government, or in regional ordinances from the regional water authorities. For specific projects constructing or modifying a water management structure by or on behalf of a water authority, a decision for the whole project, i.e. a kind of permit with regard to all relevant effects on the water system and its direct environment, is necessary. Such a project plan is laid down in Article 5.4 of the Water Act.

\section{Weaknesses in the Dutch Water Governance System}

The previous section showed the main features of the Dutch water governance system for the implementation of the WFD, with its regional water authorities based on hydrological scales and powers to regulate, decide and raise taxes for their water tasks. Furthermore well designed bridging and cooperation and coordination mechanisms exists to fulfil the needs for integrated water management based on a river basin approach. ${ }^{32}$ It is therefore understandable that EU institutions and other Member States consider the Dutch system an interesting potential source of inspiration. Yet, it is not all gold what shines. In this section, we show some weaknesses of the Dutch water management system, therefore showing what needs to be taken into consideration when considering importing (parts of) the Dutch experience into other Member States. In light of the discussion taking place in the Dutch Parliament on this issue, ${ }^{33}$ we focus on the most controversial aspects of the Dutch implementation of the WFD. First, we consider the binding force of the Dutch quality standards implementing those under the Directive (section 3.1). Second, we look at the linkage between

$32 \quad$ H.K. Gilissen et al., Bridges over Troubled Waters - An Interdisciplinary Framework for Evaluating the Interconnectedness within Fragmented Flood Risk Management Systems, Journal of Water Law 2016, 25 (1), pp. 12-26; H.F.M.Wvan Rijswick \& A.M. Keessen, The EU approach for Integrated Water Resource Management: Transposing the EU Water Framework Directive within a national context - key insights from experience, in R.C. Alistair, A. Andrew \& S. Hendry (eds.), Routledge Handbook of Water Law and Policy, Routledge 2017, pp. 51-64.

33 Question of SGP-member Bisschop of 25 September 2015, 2015Z17417; Answered on 12 October 2015, Aanhangsel Handelingen II 2015/16, nr. 273. 
such standards and the assessment of human activities potentially affecting their achievement (section 3.2). Third, we look at monitoring (section 3.3) and, finally, we look at the net-loss approach (section 3.4).

\subsection{The Binding Force of Quality Standards}

The general goal of the Directive is to establish a framework for the protection of inland surface waters, transitional waters, coastal waters and groundwater (Article 1). This general goal is further refined in more specific goals, often placed in a mutual relationship. ${ }^{34}$ This makes the Directive a complex and difficult piece of legislation which is at times difficult to grasp, to paraphrase the words of AG Jääskinen. ${ }^{35}$ As regards the environmental goals for surface water, Article 4(1)(a) of the Directive establishes that:

(i) Member States shall implement the necessary measures to prevent deterioration of the status of all bodies of surface water, subject to the application of paragraphs 6 and 7 and without prejudice to paragraph 8;

(ii) Member States shall protect, enhance and restore all bodies of surface water, subject to the application of subparagraph (iii) for artificial and heavily modified bodies of water, with the aim of achieving good surface water status at the latest 15 years after the date of entry into force of this Directive, in accordance with the provisions laid down in Annex v, subject to the application of extensions determined in accordance with paragraph 4 and to the application of paragraphs 5,6 and 7 without prejudice to paragraph 8 ;

(iii) Member States shall protect and enhance all artificial and heavily modified bodies of water, with the aim of achieving good ecological potential and good surface water chemical status at the latest 15 years from the date of entry into force of this Directive, in accordance with the provisions laid down in Annex v, subject to the application of extensions determined in accordance with paragraph 4 and to the application of paragraphs 5,6 and 7 without prejudice to paragraph 8 ;

Such goals are binding in all phases of the decision making. ${ }^{36}$ They do not only set out the goals of the Directive in a programmatic manner, ${ }^{37}$ meaning that

34 J.J.H. van Kempen, Europees waterbeheer: eerlijk zullen we alles delen, BJu 2012, pp. 119-122.

35 Opinion of AG N. Jääskinen of 23 October 2014 in Case C-461/13, Bund für Umwelt und Naturschutz Deutschland eVv Bundesrepublik Deutschland, ECLI:EU:C:2014:2324, point 4.

36 Case C-461/13 Weser ECLI:EU:C:2015:433, para. 31

37 Id., para. 43 . 
they must be respected regardless of the long-term effects of a water plan. ${ }^{38}$ Furthermore, they must be achieved as regards all water bodies falling under the WFD, regardless of whether they have been designated as a protected water body in a national or regional water plan..$^{39}$

In the Netherlands, quality standards for surface water are established in accordance to Chapter 5 of the Environmental Management Act (EMA - Wet milieubeheer), ${ }^{40}$ as referred to in Article 2.10 of the Water Act. ${ }^{41}$ Yet, only the quality standards for the chemical status of water surfaces have been established in accordance with an Order in Council based on Chapter 5 of the EMA (the so-called Besluit kwaliteitseisen en monitoring water 2009 - Bkmw 2009). ${ }^{42}$ This Order establishes that the goals are bindings and the derogation in a water plan can occur only under specific circumstances. This circumstances are directly based on the text of article 4 of the WFD. ${ }^{43}$ For the ecological status a division has been made between natural waters on the one hand and artificial, or heavily modified, waters on the other. It should be noticed that in the Netherlands about $96-99 \%$ of waters are classified as artificial or heavily modified water. ${ }^{44}$ Yet, the Bkmw 2009 only establishes that the definition of good ecological status provided for in Annex V, paragraph 1.2, tables 1.2.1 till 1.2.4, of the WFD apply in the Netherlands as quality standards. ${ }^{45}$ Additional

38 Id., para. $5^{0 .}$

39 Id., para. 55. See also C. Dieperink et al., supra note 8, pp. 16o-173.

40 Stb. 1979, 442, last amended by Stb. 2013, 20.

41 Stb. 2009, 107, last amended by Stb. 2015, 399.

42 Stb. 2010, 15, last amended by Stb. 2015, 394.

43 Explicitly required since 1 January 2016, Stb. 2015, 394. The nature of the obligation has long been discussed in Dutch literature, see eg H.E. Woldendorp \& M. Thijssen, Waterkwaliteitseisen: waterdicht geregeld?, M en R 2009, pp. 568-578; H.E. Woldendorp, Regulering van de waterkwaliteit: sluitstuk van de implementatie van de Kaderrichtlijn water (I en II), BR 2010, pp. 293-315 en 382-394; Ch.W. Backes, A.M. Keesen \& H.F.M.W. van Rijswick, Effectgerichte normen in het omgevingsrecht, BJu 2012, pp. 90-92; H.F.M.W. van Rijswick, De betekenis en vormgeving van waterkwaliteitseisen, M en R 2007, pp. 395-407, W.M. Janse \& H.F.M.W. van Rijswick, De programmatische aanpak in het waterbeheer: een les voor de Omgevingswet?, M en R 2012, p. 246. See also Van Kempen supra note 34, pp. 45-88 en 127-184.

44 Commission Staff Working Document Member State: Netherlands accompanying the document Report from the Commission to the European Parliament and the Council on the Implementation of the Water Framework Directive (2000/6o/EC), River Basin Management Plans, Сом(2012) 670 final, pp. $33^{-38}$.

45 Article 6(1)WFD;Ch.W.Backes \& H.F.M.Wvan Rijswick, Effective environmental protection: towards a better understanding of environmental quality standards in environmental legislation, In L. Gipperth \& C. Zetterberg (eds.), Miljörättsliga perspektiv och tankevändor, Vänbok till Jan Darpö \& Gabriel Michanek, Uppsala: Iustus Förlag AB 2013, pp. 19-50. 
specification is required to give concrete content to these abstract definitions. In this regard, the government has explicitly decided not to provide binding standards for the good ecological status and for the good ecological potential. ${ }^{46}$ The parameters used to establish the ecological status of 'natural' waters (hence for $1-4 \%$ of Dutch waters) are, in accordance with Article 2 of the Ministerial Order on monitoring (so called Regeling monitoring Kaderrichtlijn water $(\mathrm{Rmkw}),{ }^{47}$ indicated in the so-called stowA-parameters, which is a report written by experts. ${ }^{48}$ For artificial or heavily modified waters, the sTOWA establishes a guideline for setting the standards that apply to a specific water body. ${ }^{49}$ These standards are then inserted in the management plans for each specific water body. ${ }^{50}$ Accordingly, there is no legally binding standard. ${ }^{51} \mathrm{In}$ light of the EU requirements concerning the implementation, ${ }^{52}$ this practice can hardly be considered to be in line with Eu law.

Another difference between the WFD and the Dutch implementation thereof concerned the geographical scope of application of the standards. The goals of the Directive must be achieved in all water bodies. ${ }^{53}$ The Bkmw 2009 and the Rmkw only applies to designated waters, but in practice the competent authorities agreed voluntarily to use the same standards for not designated waters.

\subsection{The Linkage between Quality Standards and Specific Projects}

In Weser, the Court of Justice clarified that: "These matters confirm the interpretation that Article 4(1)(a) of Directive 2000/6o does not simply set out, in programmatic terms, mere management-planning objectives, but has binding

46 Nader rapport Bkmw 2009, attached to Kamerstukken II 2009/10, 27625, 154, pp. 4-5.

47 Stcrt. 2010, 5615, last amended Stb. 2015, 38398.

48 D.T. van der Molen et al. (eds.), Referenties en maatlatten voor natuurlijke watertypen voor de Kaderrichtlijn water 2015-2021, STOWA 2012-31, Utrecht: Stowa 2012.

49 Projectgroep Implementatie Handreiking, Handreiking MEP/GEP, STOWA 2006-2, RIZA/ Stowa 2006.

5o See the so-called KRW-factsheets, available at www.waterkwaliteitsportaal.nl under 'Rapportage', 'Factsheets definitief december 2015'.

51 A.A. Freriks et al., Zover het eigen instrumentarium reikt: Een onderzoek naar de positie van de provincie Noord-Brabant en de Noord-Brabantse waterschappen bij de realisatie van de Kaderrichtlijn waterdoelstellingen, met bijzondere aandacht voor de Omgevingswet, 2016 pp. 15-16; available at www.uu.nl/ucwosl, under 'Adviezen'.

See in particular Case C-361/88, Commission v Germany, ECLI:EU:C:1991:224 (TA Luft); more recently Case C-648/13, Commission v Poland, ECLI:EU:C:2016:490, stating that provisions of directives must be implemented with unquestionable binding force, and the specificity, precision and clarity necessary to satisfy the requirements of legal certainty. Weser case, para. 55. See also C. Dieperink et al. supra note 8, pp. 160-173. 
effects, once the ecological status of the body of water concerned has been determined, at each stage of the procedure prescribed by that directive." ${ }^{54}$ The goals of the Directive are therefore binding also as regards authorisation procedures of specific projects.

The Dutch government negates the existence of a direct link. ${ }^{55}$ It considers an indirect link enough to ensure compliance with the Directive. ${ }^{56}$ Such an indirect link works as it follows. As a general rule, activities affecting a water body need an authorisation to take place. Under Article 6.1a of the Water Decree, competent authorities have to take a water management plan into account when granting a water permit. Such a permit must be denied if the activities hampers the achievement of the goals established under the Water Act, and such a breach cannot be avoided by means of permit requirements or compensatory measures. ${ }^{57}$ Given that the quality standards of the Directive are included into water management plans, the government considers this form of indirect link, i.e. through the medium of the water management plan, sufficient to ensure compliance with the Directive. Five remarks can be made in this regard.

First, when a public water work is executed under Article 5.4 of the Water Act, ie when a project plan is required, there is no legal obligation to comply with a water plan of a higher competent authority. From a political and governance perspective the competent authority for a project plan - the daily board of a water authority - will take its own water plan into account despite the fact that a water plan is established by the general board. This is for example the case for river restoration projects for example to restore natural river banks. ${ }^{58}$ In practice, water authorities seem to take account of the goals of the Directive during this kind of authorization procedures. ${ }^{59}$ Yet, it is unclear the extend by which this is the case.

54 Weser case, para. 43.

55 Kamerstukken II, 2009-2010, 32 427, nr. 3, p. 3 and Kamerstukken II, 2015/16, 31 710, nr. 44.

$56 \quad$ Kamerstukken II 2015/16, 31710, 44.

57 Article 6.21 of the Water Act i.c.w. article 2.1 of the Water Act. The Management Plan for National Waters include a chapter on the assessment of individual decisions (Toetsingskader voor individuele besluiten). Many local water management plans do not have similar chapters.

$5^{8}$ This is possible on the basis of a project plan. Certain of such plans have been reviewed in court, see eg Dutch Council of State (ABRvS) 13 April 2016, ECLI:NL:Rvs:2016:972; Tribunal Oost-Brabant (Rb. Oost-Brabant) 4 September 2015, ECLI:NL:RBOBR:2015:5241; and Rb. Oost-Brabant 7 October 2014, ECLI:NL:RBOBR:2014:5982.

59 For example, in the chapter on the assessment framework in the Managing Plan for National Waters is stated that Rijkswaterstaat applies this framework also for its own projects. Moreover the Managing Plan for National Waters contains a model project plan, 
Second, the Water Act and the water management plans apply only as regards activities for which the water body authorities are competent. Yet, especially the ecological status of water bodies can be affected by activities which are not covered by these acts and fall under the competence of other authorities and policy domains. ${ }^{60}$ For example, the ecological status could be affected by agricultural fertilizers, anti-bugs products, air pollution precipitations, and medicinal residues in sewage waters. These activities are covered by other acts, for which public authorities, other than water public authorities are competent. A specific link between the Water Act and water management plans and such other acts is missing. Yet, the Ministry for Infrastructure and Water Management and the Ministry for Economic Affairs and Climate Policy are both signatory of the national water plan. In this manner it is assumed that these two public authorities will take account of the standards set out under the Water Act and in the national water plan. ${ }^{61}$ Whether this assumption is correct and what occurs in those cases in which other public authorities then these two ministries are competent to take measures is unclear.

Third, the formula 'taking into account' used to introduce the quality standards suggests that public authorities can derogate from the quality standards as indicated in a water plan if they can motivate this decision. ${ }^{62}$ This suggests that the binding force of the quality standards is less stringent that indicated by the Court of Justice, which allows derogations only if the conditions of, in particular, Article 4.7 of the Directive are met.

Fourth, there is a growing tendency to replace the authorization system with generally binding rules. ${ }^{63}$ Accordingly, there is no-ex ante assessment of human activities potentially affecting water bodies. This is not what is required by the WFD, as evincible from the Weser case, in which the court refers to any specific project, ${ }^{64}$ and the manner in which Article 4.7 of the Directive

including a section showing a model assessment in conformity with the quality standards of the Directive.

6o See also A.A. Freriks et al. supra note 51.

61 It is unclear what the effects of the Dutch specialty principle are on the possibility to take into consideration the goals under the WFD in the context of decision making based on different acts than those implementing the Directive.

62 See also B.A. Beijen (ed.), Hoofdlijnen milieubestuursrecht, BJu 2015, p. 83.

63 See A.P.W. Duijkersloot et al., Algemeen geregeld, goed geregeld?', 2011, pp. 576-585. For the water authority 'Hoogheemraadschap van Rijnland' is the approach even 'yes, unless', see Toelichting op de Keur Rijnland 2015, p. 1.

64 Case C-346/14, Commssion v Austria, ECli:Eu:C:2016:322 (Schwarze Sulm), para. 56 . 
is explained. ${ }^{65}$ Although the concept of 'project 'is not defined under the Directive, ${ }^{66}$ it can be argued that it should have a meaning similar to that it has under the EIA Directive. ${ }^{67}$ The explicit link between the WFD and the EIA Directive and the need for legal certainty and coherence within the European environmental acquis, plea in this direction. ${ }^{68} \mathrm{~A}$ similar conclusion can be reached when looking at the development of water law. ${ }^{69}$ We do not argue that the WFD requires the adoption of individual authorization procedures. Other instruments to comply with the goals for the WFD are possible. ${ }^{70}$ Yet, regardless of the instrument chosen to comply with the Directive, the effects of human activities must be assessed, and the worsening of water quality must be prevented. ${ }^{71}$ Whether this is possible by means of the Dutch system for general binding rules, which fully rely on ex post inspections and enforcement mechanisms is doubtful. Competent authority can set extra requirements, but this is not always possible and depends on the possibilities given in the specific general binding rule. ${ }^{72}$ Not meeting the quality standards that follow from the $\mathrm{WFD}$ is until now not a reason to set extra requirements.

Fifth and final, the legal meaning of regional water plans, which are made by the provinces, is unclear. The quality standards under the Directive are inserted in such plans. ${ }^{73}$ Yet, water permits are assessed in light of the water management plans of regional water authorities. These management plans are

65 Wezer case, paras. 32, 33 en 47. See also the manner in which the system for exceptions under the Directive is interpreted at para. 47. See also Schwarze Sulm case, para. 56.

66 From the Weser case and the Schwarze Sulm case it can be derived that this concept covers, in any case, the deepening of rivers and the building of water power plants.

67 Directive 2011/92/EU of the European Parliament and of the Council of 13 December 2011 on the assessment of the effects of certain public and private projects on the environment [2012] OJ L 26/1.

68 For the explanation of the meaning of this concept under both directives see N. De Sadeleer, Assessment and Authorisation of Plans and Projects Having a Significant Impact on Natura 2000 Sites, in: B. Vanheusden en L. Squintani, (eds.) EU Environmental and Planning Law Aspects of Large-Scale Projects, 2nd EELF Book Series, Intersentia 2016, pp. 281-320, op pp. 286-294, with reference to case law.

69 See annotation of H.F.M.W. van Rijswick to Case C-346/14, Commission v Austria, ECLI:EU:C:2016:322 (Schwarze Sulm), para. 56, AB 2016/242.

70 See those mentioned in Article 11(3) WFD for example.

71 Weser case, para. 50.

72 E.g. Dutch Council of State (ABRvS) 28 June 2017, ECLI:NL:Rvs:2017:1682.

73 M. Aerts \& $P$. de Putter, Is de nieuwe generatie waterplannen in een goede toestand?, M en $\mathrm{R} 2009$, p. $560 \mathrm{ff}$ showing that this was not the case in the first generation water plans. 
made by water authorities. Such management plans should include quality standards, but this is not always the case in practice. ${ }^{74}$

In summary, the Dutch government has decided to link quality standards to specific activities only indirectly, i.e. through the medium of water plans. Yet, the scope of application and the binding force of such plans is unclear. In this perspective, the Netherlands does not seem to comply with the WFD.

\subsection{Monitoring}

As discussed in the previous section, for surface water, the WFD aims at a good quality status, unless one of the exemptions under Article 4 apply. The manner to establish this status is provided in the Directive. Indeed, there are two groups of quality elements: the ecological quality and the chemical quality. The ecological element group is further sub-divided in three groups of quality elements: biological elements (water plants and animals), chemical and physicochemical elements (e.g. oxygen and nutrient levels), and hydro-morphological elements (water flows and levels; the condition of beds, banks and shores; and the continuity of rivers for fish migration), with the latter two sub-categories being supportive of the first one. In turn, each of these sub-groups are composed by specific elements. For example, the biological elements group is composed by a series of elements specified for each of the five kinds of water bodies covered by the Directive, i.e. rivers, lakes, transitional waters, coastal waters, and artificially and heavily modified surface water bodies.

As an example, the biological elements for rivers are: composition and abundance of aquatic flora, composition and abundance of benthic invertebrate fauna, and composition, abundance and age structure of fish fauna.

Each element of the biological elements group can be classified in accordance with one of the following five quality classes: high $(\mathrm{H})$, good $(\mathrm{G})$, moderate $(\mathrm{M})$, poor $(\mathrm{P})$, and bad $(\mathrm{B})$. Chemical and physicochemical elements can only influence status down to moderate and hydro morphological elements down to good. As regards the chemical status, the WFD makes use of the quality standards for priority substances and/or priority hazardous substances established under the Environmental Quality Standards Directive (Directive 2008/105/EC). Water bodies either comply (good - G - corresponding to gH in a five staged scale) or not (fail - F - corresponding to a $\mathrm{M}$ in a five staged scale) with this

74 E.W. ten Heuw, Waterkwaliteit in de juridische spotlights, het Waterschap 2016/10, p. 31. See, specifically for Noord-Brabant, Freriks et al, supra note 51, pp. $66 \mathrm{ff}$. 
quality standards. The worst of the ecological or chemical elements determines the classification of the quality class for a water body, so-called one-outall-out principle. ${ }^{75}$ Figure 2 provides a visualisation of such system.

The Weser judgment makes clear that the prohibition of deterioration under Article 4 of the Directive does not apply at the level of overall surface water quality status, i.e. the quality status established at the hand of the worst ecological or chemical group for a water body as a whole. It applies at the level of each sub-element, e.g. an element of the biological quality elements. From the perspective of the ecological status, this means that one should look at the first of the four qualification moments, i.e. the qualification of a specific element, the qualification of the overall elements sub-group (e.g. biological quality elements), the qualification of the overall ecological status, and the qualification of the overall surface water status. From the perspective of the chemical status, this means that one should look at the first of the three qualification moments, i.e. the qualification of a specific substance, the qualification of the overall chemical status and the qualification of the overall surface water status.

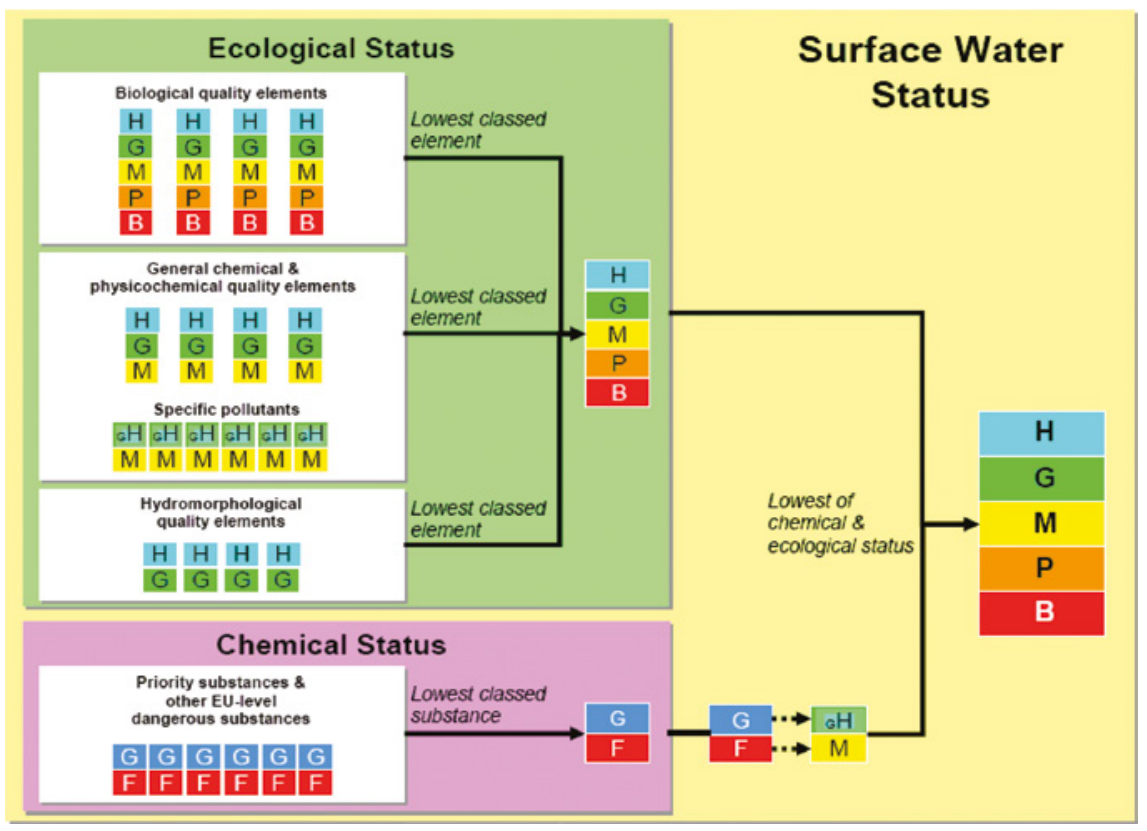

FIGURE 2 The relationship between the qualifications of individual ecological and chemical elements and the qualification of the surface waters status for a whole water body ${ }^{76}$

75 Annex V, points 1.4.2, under i, to the Directive.

76 Source: http://www.gov.scot/Publications/2010/03/02155205/4. 
Deterioration under the Directive is when the quality class of any of the elements covered by the ecological or chemical groups is worsened to an extent that it falls in a lower class. ${ }^{77}$ When an ecological or chemical element already falls under the lowest quality class established for that element, any form of further worsening is a deterioration.

Whether deterioration will potentially take place, has to be established by means of monitoring. ${ }^{78}$ The Directive refers to three different kinds of monitoring, i.e. surveillance monitoring, operational monitoring and investigative monitoring. ${ }^{79}$ The Court of Justice in Weser has not linked the concept of nondeterioration to one of these three kinds of monitoring. Yet, given that operational monitoring aims at assessing any changes in the status of such bodies resulting from the programmes of measures, this seems the kind of monitoring than needs to be used to assess whether or not deterioration occurs under the Directive. This means that the monitoring of water quality must happen at the locations and intervals of time indicated for operational monitoring, which differ from those for surveillance monitoring. ${ }^{80}$

In the Netherlands, under the Bkmw 2009 the distinction between surveillance and operational monitoring is not evident. These two kinds of monitoring seems to have been merged. ${ }^{81}$ The difference between surveillance and operational monitoring is only made in one of the 'policy' documents referred to in the Ministerial Decree on the establishment of a monitoring programme under the WFD (Rmkw), ${ }^{82}$ which is based on the Bkmw 2009. ${ }^{83}$ This policy document refers to the requirements for the locations and intervals of time prescribed by the WFD. Yet, this document only has guiding force, as evincible from its very title, which uses the word richtlijn (guideline). ${ }^{84}$ There is no legal requirement concerning the responsibility to select a monitoring location. Under the Bkmw 2009, the responsibility for implementing the monitoring programme for surface waters rests with the authority that grants the discharge permit under the Water Act. ${ }^{85}$ This is problematic for two reasons.

77 Weser case, paras. 55-70.

78 B.A. Beijen, H.F.M.W. van Rijswick \& H.T. Anker, The Importance of Monitoring for the Effectiveness of Environmental Directives, A Comparison of Monitoring Obligations in European Environmental Directives. Utrecht Law Review 201410 (2), pp. 126-135.

79 Article 1.3.1 till 1.3.3 of Annex v to the Directive.

80 Article 1.3.4 of Annex v to the Directive.

81 Explanatory Note to the Bkmw 2009, Stb. 2010, 15, p. 72.

82 The Dutch name is 'Richtlijn KRW Monitoring Oppervlaktewater en Protocol Toetsen \& Beoordelen', 2014.

83 Stcrt. 2010, 5634, last amended by Stcrt. 2015, 38397.

84 Available at www.kaderrichtlijnwater.nl.

85 Article 14 of the Bkmw 2009. 
First of all, authorities competent for the discharge permit under the Water Act are used to work on the basis of the chemical status. Given that the Directive is based on a mixture of chemical and ecological status, it is unclear how the ecological status is taken into consideration by the authority for the discharge permit. In this respect, we repeat here that the requirements concerning the ecological status are not implemented by means of binding requirements. Hence, although the ecological status is part of the assessment framework for the discharge permit, ${ }^{86}$ the specificity of the assessment of the ecological status is unclear.

Second of all, the monitoring programme under the Rmkw, which is based on a Guidance from the European Commission, ${ }^{87}$ clearly refers to the possibility of merging water bodies for the purpose of monitoring. According to the Commission's Guidance, merging is possible when enough waters of each type are monitored and there are enough monitoring points to assess the status of water. ${ }^{88}$ Further, the selection of monitoring points must occur is such a manner that an acceptable level of trustfulness of the data can be ensured. Finally, merging is possible only for water bodies of the same type.

As regards these instructions, it can be noticed, first, that the legal validity of the information included in the Commission's Guidance is unclear, as only the Court of Justice can provide binding interpretations of the Directive. ${ }^{89}$ Second, it is debatable whether the manner in which merging occurs in the Netherlands takes sufficiently into account the indications provided by the Commission. The Dutch guidance does not explain how the conditions set out in the Commission's Guidance are considered. Especially the requirement that only water bodies of the same type can be merged seems to be less relevant than under the Commission's Guidance. This can affect the trustfulness of monitoring and therefore the full implementation of the requirements of the Directive. Indeed, by collecting data at a point in which the water quality of different water bodies merges, it is difficult, if not impossible, to assess the

$86 \quad$ Article 2.1 in conjunction with Article 6.21 of the Water Act.

87 European Commission, Common Implementation Strategy for the Water Framework Directive (2000/6o/EC), Guidance Document No. 7. Monitoring under the Water Framework Directive, 2003. See on the Common Implementation Strategy J. Scott \& J. Holder, Law and New Environmental Governance in the European Union, in: G. de Búrca \& J. Scott (eds.), Law and New Governance in the EU and the US, Hart Publishing 2004, pp. 226-233.

88 European Commission Common Implementation Strategy for the Water Framework Directive (2000/6o/EC), Guidance Document No. 7. Monitoring under the Water Framework Directive, 2003.

89 It is not clear yet how the ECJ will deal with these kinds of soft law documents, see Scott \& Holder supra note 87, pp. $239 \mathrm{ff}$. 
effect that a specific project has on one specific water body, as required under the Directive. There is the danger that pollution in one water body is diluted over another one. ${ }^{90}$

\subsection{The Room for a Net-loss Approach}

The indirect manner in which the quality standards of the Directive are linked to specific human activities is also called programmatic approach. ${ }^{91}$ The programmatic approach allows room for flexibility, which can be used to foster innovative, sustainable development, facilitate the adoption of preventive measures, and a fair allocation of room for economic development and related environmental costs, including in those cases in which quality standards are not yet met. ${ }^{92}$ Moreover, flexibility can be used to cope with socio-economic and environmental development, on the one hand, and development in the state of knowledge, on the other. This latter aspect is referred to as adaptability or adaptiveness. ${ }^{93}$ These positive features have a backside. Indeed, flexibility can affect legal certainty and, consequently, enforceability and judicial protection. ${ }^{94}$ We have discussed about this approach in general, under Eu law in another publication..$^{95}$ Here we focus on the net-loss approach (in Dutch saldering) which is an instrument to create space for development within a programmatic approach. ${ }^{96}$

$90 \quad$ See H.E. Vlek \& P.P.H. Verdonschot, Knelpuntenanalyse toestand- en trendmonitoring KRW, Alterra-rapport 1175, Wageningen 2005, pp. 55 ff., who point at some difficulties regarding monitoring.

91 Janse \& Van Rijswick supra note 43, pp. 242-253.

92 Cf. Backes \& Van Rijswick supra note 45, pp. 19-50.

93 Carl Folke et al., 'Adaptive governance of social-ecological systems', Annu. Rev. Environ. Resour. 2005 (30), 441-473.

94 M.M. van Rijn-Bogaart, Flexible directives: towards a better environment? Diss. University of Amsterdam, 2017; S. van Holten \& M. van Rijswick, The consequences of a governance approach in European Environmental directives for flexibility, effectiveness and legitimacy, in M. Peeters \& R. Uylenburg (eds.), Eu environmental legislation - Legal perspectives on regulatory strategies, Edward Elgar Publishing (2005) pp. 13-47, at 30; O. Green et al., 'EU Water Governance: Striking the Right Balance between Regulatory Flexibility and Enforcement?', Ecol. Soc., 2013 (18) p. 10 and F.A.G. Groothuijse \& R. Uylenburg, Everything according to plan? Achieving environmental quality standards by a programmatic approach, in: M.G.W.M. Peeters \& R. Uylenburg (eds.), Eu Environmental Legislation. Legal Practice on Regulatory Strategies, Cheltenham, U K: Edward Elgar 2014, pp. 116-145, in particular, section 5 .

95 L. Squintani \& M. van Rijswick, Improving Legal Certainty and Adaptability in the Programmatic Approach, JEL, 2016 28(3), 443-470.

96 Groothuijse \& Uylenburg supra note 94; Backes, Keessen \& Van Rijswick supra note 43, p. 130. 
Under a net-loss approach, it is possible to balance the negative effects that one project has on an environmental quality standard with the positive effects that the same project has on a different environmental goal or with the effects that another project has on the same environmental goal. ${ }^{97}$ Depending of the specific manner in which it is shaped, the net-loss approach can take the form of mitigation or compensation measures. ${ }^{98}$

The WFD provides for a clear distinction between obligations and exemptions. Under EU law, obligations contributing to the achievement of the goals of the EU act in which the obligation is inserted are interpreted extensively. ${ }^{99}$ Conversely, exemptions to such obligations are interpreted restrictively. ${ }^{100}$ The WFD contains two main obligations, ${ }^{101}$ a no-deterioration obligation and an improvement obligation. ${ }^{102}$ The no-deterioration obligation has autonomous meaning, i.e. it is more than an instrument to achieve the improvement obligation, according to the Court of Justice. ${ }^{103}$ According to the Court of Justice in the Weser case, paragraph $5^{0}$, this means that:

It follows that, unless a derogation is granted, any deterioration of the status of a body of water must be prevented, irrespective of the longer term planning provided for by management plans and programmes of measures. The obligation to prevent deterioration of the status of bodies of surface water remains binding at each stage of implementation of Directive 2000/6o and is applicable to every surface water body type and status for which a management plan has or should have been adopted. The Member State concerned is consequently required to refuse authorisation for a project where it is such as to result in deterioration of the status of the body of water concerned or to jeopardise the attainment of good surface water status, unless the view is taken that the project is covered by a derogation under Article 4(7) of the directive.

Based on, but slightly amended, L.S. Braaksma \& K.J. de Graaf, 'De Wet natuurbescherming: natuurwetgeving vereenvoudigd?', M en $R$ 2016/91. This definition comes from Ralph Frins, see R.H.W. Frins, Mitigatie, compensatie en saldering in het omgevingsrecht, (diss. Nijmegen), Den Haag: IBR 2016.

$98 \quad$ Frins in: Braaksma \& De Graaf supra note 97.

99 For an example of this standard practice see C-473/14, Dimos Kropias Attikis, ECLI:EU:C:2015:582, para. $5^{0 .}$

100 Ib-idem.

101 Weser case, para. 39.

102 Article 4(1)(a)(ii) and (iii) of the WFD.

103 Weser case, para. 49. 
The clause 'irrespective of the longer term planning provided for by management plans and programmes of measures' used by the Court in this passage makes clear that under the WFD there are restrictions to the use of a net-loss approach. ${ }^{104}$ This also follows from article $11(5)$ of the WFD. Given the strict interpretation of the concept of non-deterioration discussed in section 3.3, a net-loss approach between different water bodies and a net-loss approach between different quality elements are excluded. ${ }^{105}$ In the Netherlands, these forms of net-loss approach are also prohibited. ${ }^{106}$

Still there seem to be two scenarios by which a net-loss approach is allowed. First of all, the clause 'unless a derogation is granted' shows that a net-loss approach can be pursued by means of one of the derogation clauses under Article 4 of the Directive. This is a special form of net-loss approach as the Eu goal that is achieved under Article 4(7) of the Directive is lower, but still allowed, than the one that it needs to be achieve under Article 4(1). Under Article 4(7) of the Directive, the net-loss approach takes the form of compensation measures. Article 4(7) of the Directive states: ${ }^{107}$

\section{Member States will not be in breach of this Directive when:}

- failure to achieve good groundwater status, good ecological status or, where relevant, good ecological potential or to prevent deterioration

104 Cf. F.M. Fleurke, Handhaving van Europees Milieurecht: resultaatsverplichtingen op het terrein van lucht en water, NtEr 2015/9, pp. 284-291. See also T. Paloniitty, The Weser Case: Case C-461/13 BUND V GERMANY', JEL 2016, 28(1), pp. 151-158. Cf. H.E. Woldendorp, Vooruitgang bij 'geen achteruitgang', Het Europese Hof over het vereiste van geen achteruitgang in de Kaderrichtlijn water (zaak C-461/13), TOO 2015/4, pp. 479-493. H.F.M.W. van Rijswick reaches a similar conclusion based on para. 57 of Schwarze Sulm case, see her annotation to this case in $A B 2016 / 242$.

105 This could also be derived from Article 11(5) of the Directive.

106 See Nader Rapport Bkmw 2009. See also Case C-43/10, Nomarchiaki Aftodioikisi Aitoloakarnanias e.a. ECLI:EU:C:2012:56o, and M. van Rijswick \& P. De Smedt, Nature conservation and water management: one battle?. In C.H. Born, et al (eds.), The Habitats Directive in its EU Environmental Law Context - European Nature's Best Hope?, Routledge 2015, pp. 417-433.

107 The other exception grounds are not considered tot o the fact that, in short, they only cover historical and natural damage Other authors speak of room for development and consider that this room is only possible based on the exceptions, see A.A. Freriks \& H.F.M.W. van Rijswick, Programmatische aanpak stikstof en programmatische aanpak water: van tweeën een?, TvAR 2015/9, pp. 399-415; A.A. Freriks \& H.F.M.W. van Rijswick, Programmatische aanpak voor natuur en water: hoe verder na het Weser-arrest, JFf 2016, vol. 13(1), pp. 3-14; and Paloniitty supra note 104. Indirectly, this means that they consider a net-loss approach possible under Article 4(7) of the Directive. 
in the status of a body of surface water or groundwater is the result of new modifications to the physical characteristics of a surface water body or alterations to the level of bodies of groundwater, or

- failure to prevent deterioration from high status to good status of a body of surface water is the result of new sustainable human development activities (...)

This provisions shows that the net-loss approach is possible only in two scenarios. First, it is possible when failures to achieve the prescribed quality standards are due to new modifications to the physical characteristics of a surface water, as in case of the building of new channels or the strengthening of a dike. Second, it is possible when a surface water body deteriorates from a high status to a good status to allow new sustainable human development activities. ${ }^{108}$ The scope of application of this particular kind of net-loss approach is thus quite limited. Moreover, under both scenario's in order to make use of this derogation, Member States must fulfil six cumulative requirements. From these requirements it appears that Member States must argue that, in particular:

(a) all practicable steps are taken to mitigate the adverse impact on the status of the body of water; (...)

(c) the reasons for those modifications or alterations are of overriding public interest and/or the benefits to the environment and to society of achieving the objectives set out in paragraph 1 are outweighed by the benefits of the new modifications or alterations to human health, to the maintenance of human safety or to sustainable development, and

(d) the beneficial objectives served by those modifications or alterations of the water body cannot for reasons of technical feasibility or disproportionate cost be achieved by other means, which are a significantly better environmental option.

In the Netherlands first of all it is questionable whether it is possible to comply with these requirements. ${ }^{109}$ Indeed, the exception ground provided for by Article 4(7) of the Directive is not explicitly mentioned in the Water Act or

108 See over the exemptions, J.J.H. van Kempen \& H.E. Woldendorp, 'Waterkwaliteit versus duurzaamheid - Een bespreking van een arrest van het Hof van Justitie van de Europese Unie over de toepassing van artikel 4, zevende lid, van de Kaderrichtlijn Water als uitzondering op het achteruitgangsverbod (HvJ EU van 4 mei 2016, ECLI:EU:C:2016:322, (Schwarze Sulm))', TOO 2016/3, pp. 390-398.

109 Cf. Woldendorp supra note 104, p. 491. 
the Water Decree. ${ }^{110}$ Second, there seem to be only few cases in which the scenario's envisaged under Article 4(7) of the Directive can occur in the Netherlands. As regards new modifications to the physical characteristics of a surface water body, such as channelling, or alterations to the level of bodies of groundwater, in practice they rarely seem to play a role in the context of the nondeterioration obligation. ${ }^{111}$ As regards new sustainable human development activities, this scenario applies to water bodies which are in a high status. Yet, there are very few water bodies in the Netherlands which have such a status. Still, this scenario might have more relevance that what it seems at first glance, when we link the 'high quality status' criterion to each individual element of the ecological status of a water body, rather than linking it to the overall quality status of the water body. Given that the no-deterioration obligation applies at the level of each individual element of the ecological status, it would make sense to interpret the derogation to this obligation in the same manner.

Secondly, a net-loss approach could be pursued under the realm of Article 4(1) of the Directive, hence without the need to rely on the derogation clause. ${ }^{112}$ Basically, member states must avoid deterioration from taking place. This should occur at project level, i.e. by taking measures aiming at avoiding the negative effects created by a specific project under consideration. Indeed, the Court of Justice has explicitly excluded the relevance of the effect of the longer term planning in assessing whether a project affects the quality of a water body. Even when a plan previews the adoption of measures improving the quality of water bodies before that other measures worsen it, it cannot be considered a net-loss approach that is allowed under Article 4(1) of the Directive. An interpretation to the contrary would not only deprive the no-deterioration obligation of most of its meaning, but it would also affect the relevance of the improvement obligation under Article 4(1) of the Directive. This means that the net-loss approach should take account of the specific consequences of each specific project. Such negative consequences must be prevented. This means that the net-loss approach under Article 4(1) of the Directive must take the form of mitigation measures.

\footnotetext{
$110 \mathrm{Ib}$-idem. The exemption is included in article 3(2) Bkmw 2009.

111 Water Directors, Clarification on the application of WFD Article 4(4) time extensions in the 2021 RBMPs and practical considerations regarding the 2027 deadline, 29 May 2017.

112 In general, Freriks \& Van Rijswick 2015 supra note 107, pp. 399-415 and Freriks \& Van Rijswick 2016 supra note 107, pp. 3-14. H.F.M.W. van Rijswick \& Ch.W. Backes, 'Ground Breaking Landmark Case on Environmental Quality Standards? The Consequences of the CJEU 'Weser-judgment' (C-461/13) for Water Policy and Law and Quality Standards in EU Environmental Law', JEEPL 2015 (3-4), pp. 363-377.
} 
The concept of 'mitigation measures' is not explained under the Directive. Under nature conservation law, the Court of Justice has established a set of criteria which need to be complied with. ${ }^{113}$ These cases can be applied also in the context of the WFD, in our opinion. ${ }^{114}$ First, both Directives envisage a distinction between a no-derogation obligation and an improvement obligation. Second, under both Directives each individual project must be assessed by means of an (appropriate) assessment of the effects of that project on the quality standards. ${ }^{115}$ Finally the scope of application of both Directives overlaps to a certain extent. ${ }^{116}$ Two different interpretations of the concept of mitigation measures under these two Directives would hence lead to legal uncertainty.

Based on Sweetman, Briels and Orleans, we can establish that mitigation measures are allowed under the Habitats Directive only if these four cumulative requirements are met:

(a) the measure aims at preventing the damage caused by a specific plan/ project (functional linkage criterion);

(b) the measure must ensure that this damage (specific criterion);

(c) will be prevented (prevention criterion); and

(d) the development of such measure must be completed before the appropriate assessment is performed (no-doubts criterion). ${ }^{117}$

According to Lees, the stringency of (some of) these criteria could lead to situations in which projects developers design their projects so as to meet these requirements, although from a societal and environmental perspective it would have been better to accept failure in fulfilling them and propose well designed

113 C-521/12, Briels e.a., ECLI:EU:C:2014:330, and C-387/15 en C-388/15, Hilde Orleans e.a., ECLI:EU:C:2016:583.

114 Cf. Woldendorp supra note 104, pp. 479-493.

115 As regards the WFD see Weser case, para. 3; Schwarze Sulm case, paras. 64, 65. As regards the WFD see, C-258/11, Peter Sweetman en anderen/An Bord Pleanála, ECLI:EU:C:2013:220; see also Briels case and Orleans case.

116 On the overlap see, M.E. Sander, H.E. Keizer-Vlek \&J.G.M. van der Greft-van Rossum, Watermaatregelen in Natura 200o-gebieden. Rapportage over synergie van watermaatregelen in Natura 2000-gebieden en KRW-waterlichamen, Altera-rapport 2356, Wageningen: Alterra 2012. See also Van Rijswick \& De Smedt supra 106, pp. 417-433.

117 These characteristics built upon those of Frins, see R.H.W. Frins, Mitigatie, compensatie en saldering in het omgevingsrecht, (diss. Nijmegen), Den Haag: IBR 2016, pp. $5^{2-72}$ and Plambeck \& Squintani supra note 15 . 
compensatory measures under Article 6(4). ${ }^{118}$ Especially the no-doubts criterion could in those cases in which measures can be adopted only while developing a project, such as in the case of a noise abatement wall on the side of an extended motorway stroke, severally restrict the possibility to qualify a measure as a mitigation one. ${ }^{119}$ We agree that if the positive effects of a future measure are absolutely certain in light of the best scientific data, which means that there is no variable that could affect the certainty of this conclusion, the precautionary principle, and hence the no-doubt criterion should be considered complied with. ${ }^{120}$ Yet, in all other cases, we do not share the negative emphasis paced by Lees on this issue, as if occurring, it would be a failure attributable to project developers and public authorities, and not to the regulatory regime. With Schoukens we agree that 'averting unsustainable development is an unavoidable corollary of any effective nature conservation law'. ${ }^{21}$

The above considerations should apply also as regards the concept of mitigation measures under the WFD. In short, the net-loss approach under Article 4(1) of the Directive must take account of the specificity of each individual project and avoid the occurrence of the negative effects of that project. ${ }^{122}$ This will mostly be the case for a net-loss approach that take place at project level. Yet, this does not mean that the net-loss approach cannot be pursued within a programme of measures. This is, in our opinion, possible if the programme of measures includes measures aiming at avoiding deterioration coming from the specific project taken into consideration.

Whether the Netherlands implemented the Directive correctly on the issue of the net-loss approach is unclear. The legal framework does not provide sufficient information to establish which kind of net-loss approach is allowed. Ambiguous is whether a generic measure in a programme of measures suffices. ${ }^{123}$ Moreover, the lack of clarity as regards the monitoring requirements

118 E. Lees, Allocation of Decision-Making Power under the Habitats Directive, Journal of Environmental Law 2016 (28), pp. 191-219, at 201.

119 R.H.W. Frins, Het arrest Orleans e.a.: het PAS en natuurmaatregelen veroordeeld tot de brandstapel?, in (2016) 147 TвR.

120 Id. See also Case C-142/16 European Commission v Germany ECLI:E U:C:2017:301, in which the Court relied on Orleans without quoting the passage referring to the no-doubt criterion. Still this was not necessary considering the specificity of the case.

121 H. Schoukens, Habitats Restoration Measures as Facilitators for Economic Development within the context of EU Habitats Directive: Balancing No Net Loss with the Preventive Approach?, JEL 2017(1), pp. 47-73.

122 See also Woldendorp supra note 104, pp. 492-493.

123 Kamerstukken II, 2015/16, 31 710, nr. 44, p. 9. 
discussed in section 3.3 means that it is difficult to link the status of a water body with a specific project. De facto, this would allow a net-loss approach. ${ }^{124}$ If this is the case, we are of the opinion that the Netherlands does not comply with the Directive.

\section{$4 \quad$ Conclusions}

It cannot be denied that the Dutch water governance system has great potentials. Yet, in section 3 we showed that there are still some points of concern.

The most important one is the manner in which the quality standards for ecological elements are implemented within the Dutch legal framework. At the moment of writing this contribution, they are not inserted in a legal binding document, but only in plans which are binding only upon the authorities that have established the plan. These authorities have jurisdiction only as regards certain human activities. Accordingly, the quality standards for the ecological status of waters cannot be enforced as regards several human activities affecting water quality, such as agriculture. This issue is exacerbated by the fact that in the Netherlands several human activities do not require a permit to be undertaken. Hence, even when such activities fall under the jurisdiction of a competent authority which has included the ecological quality standards in its water plan, deterioration cannot be prevented.

Another major finding concerns monitoring. The monitoring guidelines there is no binding requirement on all types of monitoring required by the WFD - do not ensure that competent authorities are able to link changes in water quality to specific projects.

In light of the above, no one should wonder that the quality of Dutch waters is what it is today. When considering using the Dutch experience as a source of inspiration in other Member States, these concerns should be taken in due account.

Woldendorp supra note 104, pp. 479-493. 